\title{
Titanium Standards for Hydrogen Content
}

\author{
J. T. Sterling, F. J. Palumbo, and L. L. Wyman
}

(August 7, 1962)

\begin{abstract}
This paper describes the preparation, analysis, and certification of a new series of standard samples. These samples consist of commercially pure titanium containing hydrogen at three levels (32 ppm, $98 \mathrm{ppm}$, and $215 \mathrm{ppm}$ ) and have been designated National Bureau of Standards Standard Samples Nos. 352, 353, and 354, respectively.
\end{abstract}

\section{Introduction}

The recent certification of National Bureau of Standards Standard Samples Nos. 352, 353, and 354, for hydrogen content in unalloyed titanium sheet marks the completion of (1) the lengthy process of developing suitable test methods, (2) selecting and producing adequate materials, and (3) the testing necessary for proving homogeneity and certification. The need for these standards resulted from the severe fabrication difficulties which occurred during production of titanium sheet as well as the usual desire to use these standards as reference material for specification compliance.

\subsection{Government Titanium Sheet Program}

Experiences in arrcraft design during and subsequent to World War II indicated a need for materials for aeronautic developments that had a higher strength-weight ratio and better elevated temperature performance than that of the best aluminum or magnesium alloys. Since titanium and its alloys seemed to have these requirements, the Government sponsored extensive programs for the production of titanium sponge and for the fabrication of unalloyed and alloyed sheet.

Although the sponge production program progressed without too many difficulities, the sheet materials produced were so hard and brittle that they could not be fabricated into useful shapes. As a consequence, concerted efforts were exerted to identify and remedy the source of difficulty. Therefore, it was necessary to develop new analytical procedures and techniques for determining the amounts of impurities present in the material. The data obtained were then used for correlation purposes between the physical properties and composition.
In essence, the presence of excessive amounts of hydrogen in the sheet was found to be the main offender. This early research indicated that vacuum annealing could be used as a remedial measure; however, the ultimate answer must lie in the development of metal-processing techniques, as shown by the analytical methods, which would prevent the metal and its alloys from initially accumulating hydrogen in deleterious amounts.

\subsection{Analytical Commitee}

In order to implement the analytical approach, a task group on gas analysis with Dr. T. D. McKinley, Chairman, was organized under the Metallurgical Advisory Committee on Titanium, Panel on Methods of Analysis with Mr. S. Vigo, Chairman. In brief, the efforts of this group resulted in the recommendations for analytical procedures which had been proven by a number of "round-robin tests" and by statistical analyses of the test results. These recommendations, in turn, created the need of reference standards for the hydrogen content of titanium and its alloy products. The Chemical Metallurgy Section was requested to prepare NBS Standard samples at three different levels of hydrogen content from sheet material prepared under the supervision of the Analytical Task Group.

\section{Preparation of Materials}

\subsection{Fabrication}

The titanium sheet used for making these standards was commercially pure titanium (RS-70, Heat No. R-11627) prepared by Republic Steel 
Corporation, $[1]^{1}$ South Division, Canton, Ohio under a contract funded and sponsored by Watertown Arsenal. The cost of the material for the samples was absorbed by Republic Steel Corporation, however, the processing (vacuum annealing, hydrogenation, surface grinding, and specimen cutting) was covered by the Watertown Arsenal contract and furnished to the National Bureau of Standards without charge.

One coil $33 \mathrm{in}$. wide was cold-rolled to 0.055 in. thickness, then mill annealed, descaled, and cut into twenty-four 96 in.-long sheets.

\subsection{Hydrogen Equilibration}

The program for this sheet material was directed towards the production of a series of samples at three different levels of hydrogen content in accordance with the following:

\begin{tabular}{|c|c|c|c|c|c|}
\hline Sheet No. & Group & $\begin{array}{c}\text { NBS } \\
\text { sample No. }\end{array}$ & $\begin{array}{l}\text { Hydrogen } \\
\text { aim. }\end{array}$ & $\begin{array}{l}\text { Permissible } \\
\text { limits for } \\
\text { hydrogen }\end{array}$ & $\begin{array}{l}\text { Permissible } \\
\text { limits for } \\
\text { actual anal. }\end{array}$ \\
\hline $\begin{array}{c}1-8 \\
9-16 \\
17-24\end{array}$ & $\begin{array}{l}\text { III } \\
\text { II } \\
\text { I }\end{array}$ & $\begin{array}{l}352 \\
353 \\
354\end{array}$ & $\begin{array}{r}p p m \\
30 \\
100 \\
200\end{array}$ & $\begin{array}{c}p p m \\
25-45 \\
90-110 \\
190-210\end{array}$ & $\begin{array}{r}\quad \\
\quad \pm 10 \\
\pm 5 \\
\pm 5\end{array}$ \\
\hline
\end{tabular}

The sheet stock, as produced, contained $85 \mathrm{ppm}$ of hydrogen; thus it was necessary to hydrogenate Groups I and II sheets to bring their hydrogen contents above the desired amounts. This operation consisted of submersion in a bath of sodium hydride, followed by a sulfuric acid wash to clean the sheets. Following the hydride treatment, the sheets were grit blasted in order to create a high surface-tovolume ratio which should enhance the out-gassing and equilibration treatments.

For the hydrogen equilibration treatment, the manufacturer has shown that at $1,300 \pm 5{ }^{\circ} \mathrm{F}$ $\left(704 \pm 3{ }^{\circ} \mathrm{C}\right)$ the equilibration pressures were 1,8 , and $40 \mu$ for 30,100 , and $200 \mathrm{ppm}$ hydrogen, respectively.

The procedure employed by the producer consisted of clamping each of four sheets at 2 -in. intervals within a vertical retort annealing furnace; evacuating prior to heating to prove the furnace airtight and until a leak-rate of $<60 \mu / \mathrm{hr}$ was achieved, then the heat was applied. As the load reached $750{ }^{\circ} \mathrm{F} \quad\left(399^{\circ} \mathrm{C}\right)$ the furnace was blanked off to insure against pumping off of any hydrogen. After stabilizing at the $1,300{ }^{\circ} \mathrm{F}\left(704{ }^{\circ} \mathrm{C}\right)$ level, oil-diffusion pumps were employed to attain the desired pressures. These conditions were maintained for $12 \mathrm{hr}$, following which the samples were cooled to room temperature over a period of $72 \mathrm{hr}$ under conditions which maintained uniformity of temperature throughout the sheets to less than $10^{\circ} \mathrm{F}\left(6^{\circ} \mathrm{C}\right)$ in order to minimize nonuniform distribution of the hydrogen in the sheets.

The test results on Group III (30 ppm) sheets revealed a high degree of uniformity. These sheets

\footnotetext{
1 Figures in brackets indicate the literature references at the end of this paper.
}

were nibbled into $1 / 4$ in. squares, vapor degreased, dry-tumbled, and shipped to the National Bureau of Standards.

The preliminary test results on Group I and II indicated that a hydrogen content gradient was present in the sheets. In this instance it was decided, therefore, to cut the sheets into 12 to 14 pieces 12 in. $\times 15$ in. and 18 in. $\times 15$ in. Each of these sheets was then tested and only those which had hydrogen contents within the general limits set up for the two groups were processed into $1 / 4$ in. squares and forwarded to NBS. The identities of these sheets were maintained by packaging the squares from each 12 in. $\times 15$ in. and 18 in. $\times 15$ in. sheet separately. After each sheet had been tested at NBS it was then possible to narrow the limits of the hydrogen content even further for the final samples, which are the present published limits.

\section{Test Method}

There are four basic analytical procedures available for the determination of hydrogen content of titanium. These are the vacuum-fusion, hot-extraction, equilibrium-pressure measurement, and oxidation methods.

In order to compare these methods several "round robins" have been conducted by interested groups, among which are Materials Laboratory of Wright Air Development Center [2] an ad hoc group on chemical analysis of the Materials Advisory Board Titanium Alloy Sheet Rolling Panel, and an industrial group working with titanium. It was found that the hot extraction method at $1,400{ }^{\circ} \mathrm{C}$ appeared to be the most practical method in the case of hydrogen as a considerable number of specimens can be analyzed in one working day as against four or five for the vacuum-fusion method, and good reproducible results are obtainable.

It was decided, therefore, to use the hot-extraction method at $1,400^{\circ} \mathrm{C}$ which is described in the following paragraphs. This method is now in the process of being recommended by the Metallurgical Advisory Committee on Titanium, Panel on Methods of Analysis to the American Society for Testing and Materials for certification as a standard method.

The specimens to be analyzed were selected at random from a particular group, cleaned of any oil, grease, and foreign matter by washing with ethyl ether, weighed, and inserted into the control arms of the vacuum fusion furnace. A quartz crucible was then packed with a new graphite crucible and graphite insulation inserted, and hung within the furnace assembly. The entire apparatus was then closed and vacuum slowly applied until a suitable vacuum (as observed with a McLeod gauge) was obtained with the mechanical pumps and the diffusion pumps. The furnace was slowly heated by induction to a temperature of $2,100^{\circ} \mathrm{C}$, which was maintained for approximately 1 to $1 \frac{1}{2} \mathrm{hr}$ in order to outgas the graphite crucible and provide for a sufficiently low blank correction which was considered a constant. The temperature was then lowered to an operating temperature of $1,400{ }^{\circ} \mathrm{C} \pm 20{ }^{\circ} \mathrm{C}$ and the vacuum 
checked to insure that an operating pressure of less than $1 \times 10^{-3} \mathrm{~mm} \mathrm{Hg}$ was maintained. The blank was then run, utilizing the method and collection times to be used with the specimens. If the blank was sufficiently low it was considered a constant and specimens run immediately. However, it was in the interest of accuracy and good practice that the blank correction be repeated every five or seven specimens in order to insure against any unusual or unexpected changes in values. If the blank correction was excessive, the furnace temperature was raised for another out-gassing until a suitably low blank correction was obtained.

When a suitable blank (approximately $2 \times 10^{-7} \mathrm{~g}$ $\mathrm{H}_{2}$ ) had been obtained, the specimen (being nonmagnetic) was moved along the control arm with a magnetic pusher and was introduced into the furnace at $1,400{ }^{\circ} \mathrm{C}$. At this temperature, which was below the melting point of the specimen, only the hydrogen gas was liberated and collected as a total volume of gas in the Toeppler Pump for a period of $20 \mathrm{~min}$. The gas was then transferred by the pump into a previously evacuated McLeod gage where it was measured as the total quantity of hydrogen liberated from the specimen. By using this figure and making suitable corrections for the blank and the calibration of the McLeod gauge, the percentage or parts per million of hydrogen gas in the specimen could be computed and reported.

\section{Tests and Results}

\subsection{NBS Sample No. 352}

The low hydrogen sample, designated Group III originally, now numbered NBS 352 , was originally set up to have a hydrogen content in the range 25 to $45 \mathrm{ppm}$.

Because this material from the different sheets was mixed at the manufacturer's plant, it was not possible to segregate specific batches with respect to position in the original sheets. As a consequence, random samples were selected by a quartering process from the bulk after it had been subjected to through mixing. The test results from this material are given for the individual laboratories in tables 1 to 6 , and the combined results by several cooperating laboratories are given in table 7 .

\subsection{NBS Sample No. 353}

The intermediate hydrogen sample was prepared in the same manner as the low hydrogen material. However, the test samples were selected from the nibbled specimens from the 12 in. $x 15$ in. and 18 in. $\mathrm{x} 15$ in. sections which were cut from the original sheets, as previously described.

The results for this selected material are given for the individual laboratories in tables 1 to 6 , and the summary of results obtained from the combination of the test data from the various cooperating laboratories is given in table 8 .

\subsection{NBS Sample No. 354}

The high hydrogen material was prepared in the same manner insofar as sampling is concerned as was sample No. 353. The results for the material selected for the standard are given for the individual laboratories in tables 1 to 6 , and the results obtained by the combination of the results from the various laboratories is given in table 9 .

\section{Standard Samples}

The availability of these three new standards for the hydrogen content of titanium has recently been announced by the National Bureau of Standards. A series of tests recently conducted by one of the leading producers of titanium, made on the material finally selected for the standards, gave excellent correlation with the test results shown in the following tables.

Table 1. Battelle Memorial Institute

\begin{tabular}{|c|c|c|c|}
\hline & \multicolumn{3}{|c|}{ Observed values } \\
\hline & Sample No. 352 & Sample No. 353 & Sample No. 354 \\
\hline & $\begin{array}{l}p p m \\
30.8 \\
30.8 \\
31.8 \\
30.8 \\
30.0 \\
31.2\end{array}$ & $\begin{array}{l}\text { ppm } \\
99.5 \\
94.5 \\
96.5 \\
99.5 \\
92.7 \\
95.5\end{array}$ & $\begin{array}{l}p p m \\
204 \\
208 \\
211 \\
210 \\
213 \\
217\end{array}$ \\
\hline Total No. det... & 6 & 6 & 6 \\
\hline Mean & 30.9 & 96.4 & 209.0 \\
\hline Standard dev ......... ppm _. & 6 & 2.7 & 5.9 \\
\hline Coeff. of var & 1.9 & 2.8 & 2.9 \\
\hline Range _._. & 1.8 & 6.8 & 16 \\
\hline High value & 31.8 & 99.5 & 217 \\
\hline Low value.............. ppm _. & 30.0 & 92.7 & 201 \\
\hline
\end{tabular}

Note: In tables 1 through 6 the standard deviation and coefficient of variation were computed as follows:

$$
\begin{aligned}
& \begin{aligned}
\text { Standard deviation } & =s=\sqrt{\frac{\Sigma(X-\bar{X})^{2}}{n-1}} \\
\text { where } \frac{X}{\bar{X}} & =\text { observed values, }
\end{aligned} \\
& \bar{X}=\text { average, } \\
& n=\text { number of determinations } \\
& \text { Coefficient of variation }=\frac{s}{\bar{X}}
\end{aligned}
$$

\begin{tabular}{|c|c|c|c|}
\hline & \multicolumn{3}{|c|}{ Observed values } \\
\hline & Sample No. 352 & Sample No. 353 & Sample No, 354 \\
\hline & $\begin{array}{l}\text { ppm } \\
35.9 \\
35.4 \\
34.4 \\
34.8 \\
35.3\end{array}$ & $\begin{array}{r}\text { ppm } \\
106.4 \\
106.5 \\
94.2 \\
103.2 \\
97.2\end{array}$ & $\begin{array}{l}\text { ppm } \\
218.6 \\
228.3 \\
219.8 \\
219.2 \\
217.3\end{array}$ \\
\hline & $\begin{array}{l}31.9 \\
33.6 \\
31.7 \\
33.4 \\
32.4\end{array}$ & $\begin{array}{r}106.3 \\
83.1 \\
105.3 \\
93.9 \\
103.2\end{array}$ & $\begin{array}{l}218.2 \\
221.9 \\
208.7 \\
224.1 \\
215.4\end{array}$ \\
\hline & $\begin{array}{l}34.6 \\
24.7 \\
29.0\end{array}$ & $\begin{array}{r}104.0 \\
89.1 \\
98.4 \\
113.8\end{array}$ & $\begin{array}{l}214.9 \\
226.7 \\
213.5\end{array}$ \\
\hline Total No. det. & 13 & 14 & 13 \\
\hline Mean & 32.9 & 100.3 & 219.0 \\
\hline Standard dev & 3.1 & 8.1 & 5.4 \\
\hline Coeff. of var & 9.4 & 8.1 & 2.5 \\
\hline Range. & 11.2 & 30.7 & 19.6 \\
\hline High value & 35.9 & 113.8 & 228.3 \\
\hline Low value & 24. 7 & 83.1 & 208.7 \\
\hline
\end{tabular}

TABLE 2. National Research Corporation 
Table 3. Dupont Company

\begin{tabular}{|c|c|c|c|}
\hline & \multicolumn{3}{|c|}{ Observed values } \\
\hline & Sample No. 352 & Sample No. 353 & Sample No. 354 \\
\hline & $\begin{array}{l}\text { ppm } \\
28 \\
34 \\
29 \\
30 \\
30\end{array}$ & $\begin{array}{r}\text { ppm } \\
88 \\
92 \\
101 \\
97 \\
91\end{array}$ & $\begin{array}{l}\text { ppm } \\
214 \\
207 \\
214 \\
210 \\
215\end{array}$ \\
\hline $\begin{array}{l}\text { Total No, det } \\
\text { Mean } \\
\text { Standard dev } \\
\text { Coeff, of var. } \\
\text { Range... } \\
\text { High value } \\
\text { Low value.... }\end{array}$ & $\begin{array}{r}5 \\
30.2 \\
3.1 \\
7.7 \\
6 \\
34 \\
28\end{array}$ & $\begin{array}{r}5 \\
93.8 \\
5.2 \\
5.5 \\
13 \\
101 \\
88\end{array}$ & $\begin{array}{r}5 \\
212.0 \\
3.4 \\
1.6 \\
8 \\
215 \\
207\end{array}$ \\
\hline
\end{tabular}

TABLE 4. Allegheny Ludlum Corporation

\begin{tabular}{|c|c|c|c|}
\hline & \multicolumn{3}{|c|}{ Observed values } \\
\hline & Sample No. 352 & Sample No. 353 & Sample No. 354 \\
\hline & $\begin{array}{l}\text { ppm } \\
34.4 \\
34.2 \\
34.0 \\
33.7 \\
33.5 \\
32.7\end{array}$ & $\begin{array}{l}p p m \\
105 \\
104 \\
104 \\
103 \\
101 \\
101\end{array}$ & $\begin{array}{l}p p m \\
227 \\
226 \\
222 \\
220 \\
220 \\
219\end{array}$ \\
\hline 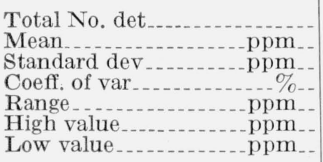 & \begin{tabular}{r}
\multicolumn{1}{c}{6} \\
33.8 \\
0.6 \\
1.8 \\
1.7 \\
34.4 \\
32.7
\end{tabular} & $\begin{array}{l}6 \\
103.0 \\
1.7 \\
1.7 \\
4 \\
105 \\
101\end{array}$ & $\begin{array}{c}6 \\
222.3 \\
3.3 \\
1.6 \\
8 \\
227 \\
219\end{array}$ \\
\hline
\end{tabular}

Table 5. Watertown Arsenal

\begin{tabular}{|c|c|c|c|}
\hline & \multicolumn{3}{|c|}{ Observed values } \\
\hline & Sample No. 352 & Sample No. 353 & Sample No. 354 \\
\hline & $\begin{array}{l}\text { ppm } \\
33.5 \\
33.4 \\
31.5 \\
29.7 \\
30.8\end{array}$ & $\begin{array}{r}p p m \\
100.9 \\
98.3 \\
99.0 \\
101.1 \\
95.8\end{array}$ & $\begin{array}{l}p p m \\
221.2 \\
216.7 \\
214.5 \\
213.0 \\
216.0\end{array}$ \\
\hline & $\begin{array}{l}31.8 \\
30.5 \\
29.8 \\
32.2 \\
32.1\end{array}$ & $\begin{array}{r}102.2 \\
101.3 \\
95.4 \\
102.1 \\
99.8\end{array}$ & $\begin{array}{l}214.7 \\
211.7 \\
221.2 \\
217.7 \\
212.0\end{array}$ \\
\hline & $\begin{array}{l}32.2 \\
30.4 \\
30.9 \\
35.0\end{array}$ & $\begin{array}{r}97.6 \\
106.2 \\
92.6 \\
101.3 \\
102.1\end{array}$ & $\begin{array}{l}213.9 \\
214.0 \\
211.6 \\
215.6 \\
216.8\end{array}$ \\
\hline 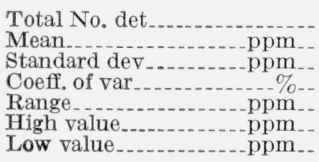 & $\begin{array}{r}14 \\
31.7 \\
1.5 \\
4.7 \\
5.3 \\
35.0 \\
29.7\end{array}$ & $\begin{array}{r}15 \\
99.7 \\
3.4 \\
3.4 \\
13.6 \\
106.2 \\
92.6\end{array}$ & $\begin{array}{r}15 \\
215.3 \\
3.0 \\
1.4 \\
9.6 \\
221.2 \\
211.6\end{array}$ \\
\hline
\end{tabular}

TABLe 6. National Bureau of Standards

\begin{tabular}{|c|c|c|c|c|c|c|}
\hline & \multicolumn{2}{|c|}{ Sample No. 352} & \multicolumn{2}{|c|}{ Sample No. 353} & \multicolumn{2}{|c|}{ Sample No. 354] } \\
\hline & $\begin{array}{c}\text { Ob- } \\
\text { served } \\
\text { values }\end{array}$ & $\begin{array}{l}\text { Fre- } \\
\text { quency }\end{array}$ & $\begin{array}{c}\text { Ob- } \\
\text { served } \\
\text { values }\end{array}$ & $\begin{array}{c}\text { Fre- } \\
\text { quency }\end{array}$ & $\begin{array}{l}\text { Ob- } \\
\text { served } \\
\text { values }\end{array}$ & $\begin{array}{c}\text { Fre- } \\
\text { quency }\end{array}$ \\
\hline & $\begin{array}{l}p p m \\
27 \\
28 \\
29 \\
30 \\
31\end{array}$ & $\begin{array}{l}3 \\
2 \\
7 \\
7 \\
6\end{array}$ & $\begin{array}{l}p p m \\
88 \\
89 \\
90 \\
91 \\
92\end{array}$ & $\begin{array}{r}1 \\
1 \\
3 \\
11 \\
11\end{array}$ & $\begin{array}{l}p p m \\
190 \\
202 \\
205 \\
206 \\
207\end{array}$ & $\begin{array}{l}1 \\
2 \\
4 \\
3 \\
1\end{array}$ \\
\hline & $\begin{array}{l}32 \\
33 \\
34 \\
35\end{array}$ & $\begin{array}{l}7 \\
6 \\
3 \\
3\end{array}$ & $\begin{array}{l}93 \\
94 \\
95 \\
96 \\
97\end{array}$ & $\begin{array}{r}14 \\
9 \\
6 \\
10 \\
16\end{array}$ & $\begin{array}{l}208 \\
209 \\
210 \\
211 \\
212\end{array}$ & $\begin{array}{r}1 \\
10 \\
16 \\
11 \\
12\end{array}$ \\
\hline & & & $\begin{array}{r}98 \\
99 \\
100 \\
101 \\
102\end{array}$ & $\begin{array}{r}12 \\
7 \\
3 \\
2 \\
1\end{array}$ & $\begin{array}{l}213 \\
214 \\
215 \\
216 \\
217 \\
\\
218 \\
219 \\
221\end{array}$ & $\begin{array}{r}8 \\
5 \\
10 \\
6 \\
6 \\
\\
4 \\
1 \\
2\end{array}$ \\
\hline 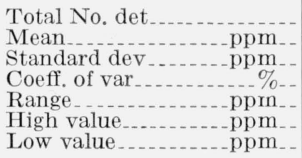 & \multicolumn{2}{|c|}{$\begin{array}{c}44 \\
31.0 \\
2.2 \\
7.1 \\
8 \\
35 \\
27\end{array}$} & \multicolumn{2}{|c|}{$\begin{array}{c}107 \\
95.0 \\
3.1 \\
3.3 \\
14 \\
102 \\
88\end{array}$} & \multicolumn{2}{|c|}{$\begin{array}{l}103 \\
211.8 \\
4.3 \\
2.0 \\
31 \\
221 \\
190\end{array}$} \\
\hline
\end{tabular}

TABle 7. Sample No. 35\%

\begin{tabular}{|c|c|c|c|}
\hline \multicolumn{4}{|c|}{ Group III } \\
\hline Laboratory & Mean & $d$ & $d^{2}$ \\
\hline $\begin{array}{l}\text { Nat'l Res. Corp } \\
\text { Watertown Arsenal } \\
\text { Battelle Mem. Inst } \\
\text { Dupont Co } \\
\text { Allegheny Ludlum Corp } \\
\text { Nat'l Bur. Standards }\end{array}$ & $\begin{array}{l}\text { ppm } \\
32.9 \\
31.7 \\
30.9 \\
30.2 \\
33.8 \\
31.0\end{array}$ & $\begin{array}{r}p p m \\
1.15 \\
-0.05 \\
-.85 \\
-1.55 \\
2.05 \\
-0.75\end{array}$ & $\begin{array}{l}1.32 \\
0.72 \\
2.40 \\
4.20 \\
0.56\end{array}$ \\
\hline \multicolumn{4}{|c|}{$\begin{array}{l}\Sigma=190.5 \\
\text { rage } 31.75\end{array}$} \\
\hline
\end{tabular}

Adopted value for Group III $32 \pm 2$ ppm

NotE: In tables 7 through 9 the 95 percent confidence limits were computed as follows:

$$
\begin{aligned}
95 \text { percent Confidence limits } & =\bar{X} \pm t \frac{s}{\sqrt{n}}, \\
\text { where } \bar{X} & =\text { average, } \\
s & =\text { standard deviation, } \\
n & =\text { number of laboratories, } \\
t & =2.571 \text { is the critical value of " } t \text { " as } \\
& \text { given, for example, by Youden [3]. }
\end{aligned}
$$


TABle 8. Sample No. 358

\begin{tabular}{|c|c|c|c|}
\hline \multicolumn{4}{|c|}{ Group II } \\
\hline Laboratory & Mean & $d$ & $d^{2}$ \\
\hline $\begin{array}{l}\text { Nat'l Res. Corp } \\
\text { Watertown Arsenal } \\
\text { Battelle Mem. Inst } \\
\text { Dupont Co } \\
\text { Allegheny Ludlum Corp } \\
\text { Nat'l Bur. Standards. }\end{array}$ & $\begin{array}{r}p p m \\
100.3 \\
99.7 \\
96.4 \\
93.8 \\
103.0 \\
95.0\end{array}$ & $\begin{array}{r}p p m \\
2.3 \\
1.7 \\
-1.6 \\
-4.2 \\
5.0 \\
-3.0\end{array}$ & $\begin{array}{r}5.29 \\
2.89 \\
2.56 \\
17.64 \\
25.00 \\
9.00\end{array}$ \\
\hline \multicolumn{4}{|c|}{$\begin{array}{cc}\Sigma=588.2 & \Sigma d^{2}=62.38 \\
\text { rage 98.0 } & \text { Standard dev. }=3.532 \\
\text { Standard error }=1.442 \\
95 \% \text { confidence limits }=98.0 \pm 3.7 \mathrm{ppm} .\end{array}$} \\
\hline
\end{tabular}

TABle 9. Sample No. 354

\begin{tabular}{|c|c|c|c|}
\hline \multicolumn{4}{|c|}{ Group I } \\
\hline Laboratory & Mean & $d$ & $d^{2}$ \\
\hline $\begin{array}{l}\text { Nat'l Res. Corp } \\
\text { Watertown Arsenal } \\
\text { Battelle Mem. Inst } \\
\text { Dupont Co } \\
\text { Allegheny Ludlum Corp } \\
\text { Nat'l Bur. Standards }\end{array}$ & $\begin{array}{r}p p m \\
219.0 \\
215.4 \\
209.0 \\
212.0 \\
222.3 \\
211.8\end{array}$ & $\begin{array}{r}\text { ppm } \\
4.1 \\
0.5 \\
-5.9 \\
-2.9 \\
7.4 \\
-3.1\end{array}$ & $\begin{array}{r}16.81 \\
0.25 \\
34.81 \\
8.41 \\
54.76 \\
9.61\end{array}$ \\
\hline \multicolumn{4}{|r|}{$\begin{array}{l}2=124.65 \\
=4.993 \\
=2.038 \\
\pm 5.2 \mathrm{ppm}\end{array}$} \\
\hline
\end{tabular}

The authors are grateful to the Watertown Arsenal, Watertown 72, Mass., and S. W. Poole and R. S. Smith, Jr., of Republic Steel Corporation, South Division, Canton, Ohio, through whose cooperation the material for these samples was obtained. Also, we extend special thanks to Horace S. Harper of this laboratory, who performed many of the analyses, and also to the following laboratories which cooperated in the final analysis of the samples with great dispatch:

Allegheny Ludlum Steel Corporation, Research and Development Laboratories, Brackenridge, Pa.W. A. Peifer; Battelle Memorial Institute, Columbus 1, Ohio-M. W. Mallett; E. I. du Pont de Nemours and Co., Pigments Department, Experimental Station, Wilmington 98, Delaware-T. D. McKinley; National Research Corporation, Cambridge 42, Massachusetts-J. P. Martin; Watertown Arsenal, Watertown 72, Massachusetts-S. Vigo.

\section{References}

[1] Final Technical Report, Republic Steel Corporation, South Division, Canton, Ohio, Watertown Arsenal Laboratories File No. 401/297.

[2] Titanium Metallurgical Laboratory Report No. 27 (Dec. 27, 1955) (PB-121607).

[3] Statistical Methods for Chemists, William J. Youden (John Wiley \& Sons, Inc., New York, 1951).

(Paper 66A6-183) 